\title{
Evaluation of English Textbook of Intermediate Class From Students' Perspectives
}

\author{
Muhammad Arfan Lodhi ${ }^{1}$, Hifza Farman ${ }^{2}$, Ihsan Ullah $^{3}$, Aiza Gul ${ }^{4}$, Fareeha Tahira ${ }^{5} \&$ Sidra Saleem ${ }^{5}$ \\ ${ }^{1}$ Higher Education Department Collegiate Wing, Punjab \\ ${ }^{2}$ National College of Business Administration Faculty, Rahim Yar Khan \\ ${ }^{3}$ School Education Department, Rahim Yar Khan \\ ${ }^{4}$ MTB College Rahim Yar Khan \\ ${ }^{5}$ NCBA\&E University Lahore \\ Correspondence: Muhammad Arfan Lodhi, Higher Education Department Collegiate Wing, Punjab, Pakistan.
}

Received: December 17, 2018 Accepted: January 18, 2019 Online Published: January 21, 2019

doi: 10.5539/elt.v12n3p26 URL: https://doi.org/10.5539/elt.v12n3p26

\begin{abstract}
Textbooks play significant role in teaching and learning continuum. Due to this reason, Curriculum wings and Directorate of staff development (Punjab) have had continuous check and monitoring in devising goals and standards in textbooks from grade 1 to grade 10 . But at intermediate level specially in 12 th grade, the same text book i.e. Good-bye Mr. Chips is being taught more than 20 years. It is assumed that there lies a huge literacy and learning gap between the secondary level English textbooks and intermediate level English textbooks. The present study keeping in view the issues and gaps in mind was an attempt to investigate the importance of English textbooks being taught at intermediate level (Grade 12) in different schools and colleges in Punjab. Prospective study occupies descriptive type of research framework. The textbook of English being taught at intermediate level is evaluated according to specified models and strategies mentioned in previous research studies based upon textbook evaluation. Sample was determined through applying cluster random sampling technique. Questionnaire was designed, validated and administered after conducting pilot phase. The findings of the study reveal that the textbook being taught at intermediate level is not be up to snuff to convene the common objectives of the target language and is irreconcilable with the requirements of promoting confidence and ornamental language skills. Moreover, it is recommended that textbooks must be revised from time to time to obtain definite language learning objectives. The book being evaluated lacks innovation, students' interest, relevant content and appropriate skills.
\end{abstract}

Keywords: textbook evaluation, learners' perspectives, language learning, linguistic content

\section{Introduction}

\subsection{Background of Study}

Textbooks occupy important stature in the teaching and learning triangle of education. As far as the language teaching is concerned, importance of textbook increases with every learning and teaching phase. Textbooks relate considerable importance in the academic growth and success of students at all levels of education (Azizifar, Koosha, \& Lolfi, 2010, p. 36). Most specifically in the field of language learning, importance of textbooks becomes more essential and undeniable as they perform the major guiding tool in giving learning input and providing help and insistence to the language learning. By the same token, the quality and efficacy of textbooks is also a great challenge in connection with their relevance to the curriculum standards and learning outcomes of students. At times, students and teachers fail to get much help from the textbook due to certain reasons that consequently hinder students' progress and performance in learning English as a second language. Furthermore, it becomes a difficult task to evaluate and assess textbooks and their benefits in relationship with the curriculum standards and students achievements (Lathif, 2015).

Many studies have been conducted on evaluating the curriculum contents of textbooks and importance of textbook in teaching and learning processes and procedures. Teachers take help from textbook in setting their instructional goals and pedagogical implications. Similarly, students benefit from textbook to fix their 
motivational strategies and learning standards. Taking all umbrella issues in mind, the present study aims to investigate the effectiveness and reliability of the intermediate level English textbooks published by Punjab Textbook Board, Lahore. Books taught in government and private schools of Punjab province from grade 1 to 12 are monitored, processed, written and published by Punjab Text Book Board (PTBB) organization. Textbooks play significant role in teaching and learning continuum. Due to this reason PTBB, Curriculum wings and Directorate of staff development (Punjab) have had continuous check and monitoring in devising goals and standards in textbooks from grade 1 to grade 10. During last decade, English textbooks have been changed consistently regarding their contents, appearances and teacher guide manuals etc in order to obtain better results from teachers and students (Government of Pakistan, 2006).

However, materials and contents at the intermediate level have not been the point of focus for the people concerned. Students are still taught the insipid and impractical contents in English at intermediate level most specially in $12^{\text {th }}$ grade. Good-bye Mr. Chips is being taught for last more than 20 years at intermediate level; where curriculum design and assessment patterns have been changed from grade one and matriculation level, same textbook and contents are taught at intermediate level. It is assumed that there lies a huge literacy and learning gap between the secondary level English textbooks and intermediate level English textbooks. The present study keeping in view the issues and gaps in mind was an attempt to investigate the importance of English textbooks being taught at intermediate level (Grade 12) in different schools and colleges in Punjab. The effectiveness and importance of $12^{\text {th }}$ grade English textbook has also been investigated from teachers' perspectives, students' perspectives and curriculum efficacy perspectives.

\subsection{Research Questions}

1) To what extent English textbook of grade 12 is effective in providing English Proficiency skills among ESL learners according to students' viewpoint?

2) How effective, English language teachers, relate the content and materials of textbook grade 12 towards their teaching practices and obtaining learning outcomes?

3) To what extent English textbook of grade 12 has been achieving curriculum goals and learning standards as devised by curriculum wing Pakistan?

4) What types of difficulties students come across while taking help from English textbook at intermediate level?

\section{Literature Review}

The true meaning of word "textbook" is to provide the complete material for a course. It focuses on providing as much as possible material in one book and is designed so that it could provide the authentic material to a learner during the course. A textbook is an almost worldwide element of teaching. No teaching process can be complete unless it has relevant textbook. In many cases the term "materials" used for in place of "textbooks", which identifying anything that is used by teachers and students to keep continue the process of learning. The term "Textbooks" is still used all around the world but its reference has expanded from books to all the materials used around or independent of the books (Richards, 2001).

\subsection{The Nature of the Textbooks}

No doubt a syllabus mentioned specific goals and aims of a course program, materials turns these goals and aims in pedagogical action. These goals and aims make a structure of a particular language learning context. For most of the teachers in world, the syllabus is just a textbook (Skierso, 1991). Even if an official syllabus is present, the teachers may have no knowledge about it or may not have access to it. The "textbook" is the most authentic and visible source of the curriculum. Materials explicate the knowledge and culture of any country or society. According to McDonough and Shaw (2003).

What gets included in materials largely defines what may content as 'legitimate knowledge'. The way materials are organized and presented, as well as the type of content and activities, will help shape a learners' view of language.

Material according cultural studies is an interdisciplinary field that tells about the relationship between people and things: the making history, preservation, and interpretation of objects (McGrath, 2002). It draws on theory and practices from the social sciences and humanities such as art history, anthropology, ethnography etc.

\subsection{Types of Textbooks}

There are several types of textbooks in learning process, it's important to know about the categories of textbooks before evaluating textbooks or series (Hussain \& Mahmood 2002). 


\subsubsection{Core Series Textbooks}

This sequence of books, usually beginning through high intermediate or advanced levels sometimes includes a literacy level as well. The four skills (listening, speaking, reading and writing) are integrated, although "many series put a stronger emphasis on listening and speaking skills development and have a life skills focus" Hrehovcik, (2002). Many series include different components such as audio-visual elements, teacher materials, web based assistance and assessment options. Most core series try to relate in some way to standardized assessment, national, state and other standards.

\subsubsection{Integrated Skills Texts}

These books also provide practice in the four skills, but they are single text instead of being the part of a leveled core series.

\subsubsection{Grammar Texts}

Some books are core grammar series and include both presentation and practice for learners. Other reference books not typically used as students, but useful for teacher and learner also.

\subsubsection{Skill Specific Texts}

These books focus on particular skills, such as listening, reading, speaking, vocabulary or pronunciation. Most commonly, such textbooks are introduced and published as part of the series of curricula.

\subsubsection{Literacy Texts}

Some books and other materials are designed specifically for learners who have limited formal education. Students go through such textbooks as part of their academics. These books are written on some specific curriculum guidelines.

\subsubsection{Content Based Texts}

These books are focused on specific subject areas such as civics or citizenship, job related topics or academics preparation. Most likely professional matters and information are discussed in such text volumes.

\subsubsection{Dictionaries}

Picture dictionaries for beginning levels and a range of English only dictionaries (from limited, with simple definitions to high advanced) for other levels can be useful for learners both in and outside of class. There are different types of dictionaries i.e. monolingual, bilingual and multilingual dictionaries etc.

\subsection{The Advantages of Textbooks}

Textbooks provide structure and curriculum for an educational program (Zohrabi, Sabouri, \& Behroozian, 2012). They help standardize instruction and maintain equality. They provide variety of learning resources. They provide effective language models and input. They are visual learning materials. They are helpful resource for self-directed learning, an effective resource for presentation material; a source of ideas and activities and can train teachers. They allow the teacher to set the learning process for students according to their experience. They help to manage the lesson, discussion and provide gradually process to learning and an authentic plan of action to teacher.

They provide security to teachers and inexperienced teachers to make decisions what to teach and how to do lesson planning. Textbooks are big source to save time, textbooks provides effective activities and ideas for learning process and language development. The main advantage of textbooks is they are psychological essential for students and we can easily measure the achievement level of students. The main advantage for students of textbooks is that they know how much material has been covered and how much material have to cover. Textbooks are the big source to familiarize the teacher and students with new changes, new ideas and methods can put easily in textbooks.

The selection of traditional language learning process, many textbooks are not up to date and may include language learning activities which are proved ineffective. Not proper helpful for teachers as a guides, some textbooks provides guidance about activities which are not helpful for teachers. Fail to recognize the modern teaching methods according to students due to insufficient of content in textbooks. Many ELT textbooks are often regarded as the tainted end-product of an author's or publisher desire for quick process (Aftab, Sheikh, \& William, 2014). Taking these points in mind and the fact that the selection of textbooks is a major educational decision which has immediate implication for the quality of student learning, it can easily be appreciated. 


\subsection{Need for Evaluation of Good-By Mr. Chips (Novel)}

The selected textbook is based upon the novel of a character named Mr. Chips. Good-bye Mr. Chips, by James Hilton in 1934, tells a story about a teacher Mr. Chips who was a teacher at Brookfield. He lives at school and never felt comfortable around women. He fell in love at the age of 48, when he was spending his summer vacations with his friend. There he saw a lad waving in his direction, he thought that she is in peril and starts to rush to her aid. However, his foot stuck between the rocks and he was rescued by a young lady Katherine Bridges. She changed him and his way of life after they get married. Tragically she died during the child birth, this incident changed Mr. Chips and he became the famous teacher at Brookfield. After his retirement he spends his time in recalling his memories and his time spend in Brookfield.

Evaluation has many purposes but the main purposes of assessment consist of probing the efficiency of the instructional subject, giving important information about the students' improvement and course development. According to Nguyen, (2015) the main purpose of assessment studies is not simply to evaluate but rather to achieve valuable information for improving the program of study and the textbooks and that can help in testing and measuring the students' achievements. The purpose of evaluation is refinement and program improvement. Evaluation studies can drop light on the points of strengths and weaknesses of the program of study in order to boost up what is good and compact with the areas that may require to be enhanced. Evaluation is to reduce gaps and preventable duplication, to provide a smoother improvement of content through a variety of levels to take away inconsistencies among numerous textbooks in diverse subjects and in different levels, and in common to provide a program of training in English more in line with the needs of the students (Foster, 2002). Textbook evaluation is a difficult matter, as there are many variables which may influence the achievement or failure of a textbook in an exact course of instruction, and in carrying out an evaluation, evaluators' need to take many decisions (Abbasian \& Khajavi, 2011). One is the selection of criteria for evaluation because no general list of criteria is perfect.

\section{Research Methodology}

Prospective study occupies descriptive type of research framework. Descriptive study focuses on the issues and information that already exist, and needs to be found and evaluated according to specified research objectives. The textbook of English being taught at intermediate level is evaluated according to specified models and strategies mentioned in previous research studies based upon textbook evaluation.

\subsection{Participants}

The population parameter for recent study comprised all the colleges and higher secondary schools of Multan districts. Additionally, teachers teaching in these colleges and schools are also the population of the study. For present study, sample was taken from both private and public colleges with equal ratio of male and female students. 200 students were selected from ten different colleges from government. and private sector in equal proportion including both male and female students from both sectors. The reason to select diverse sample is to obtain data from those participants which could generalize the whole population parameter. Researcher used multiple stage random sampling technique. At first step researcher selected 10 colleges by using purposive sampling technique. At next step, students were selected through simple random sample technique from these colleges.

\subsection{Data Collection Instrument}

In any research study, researchers use data collection tools and techniques as fact finding strategies. There are different tools used for data collection included questionnaires, interviews, case-histories, surveys etc. For recent research, data was collected by using questionnaire. Questionnaire is a systematic form of document and with a set of questions deliberately designed to elicit responses from respondents or research informants for the purpose of collecting data or information. It is an information collecting instrument and can be in both forms structured and unstructured. Recent study aimed at evaluating textbook at grade 12 level. For present research study, a questionnaire was drafted to collect data from students. This questionnaire consisted of four parts. The first part of questionnaire consisted of demographical information, second part about importance of textbook, third part was about content, vocabulary, skills, and activities. The fourth part consisted of objectives, appearance of textbook, methods of teaching and assessment. Factors related to validity and reliability issues were treated and settled during the process of pilot testing. Data collection tools were pilot tested before starting the operationalization stage of the study. To test out the worth of the research tool a pilot study was conducted. After piloting the research instrument, the questionnaire was administered on the target sample. The response rate of data collection was more than $95 \%$ that was appeasing for the researchers. 


\subsection{Delimitations of the Study}

- The study was delimited to the colleges of district Multan only.

- The study was further delimited to evaluate the English textbook being taught at grade 12 only.

\section{Data Analysis}

Data obtained from students' questionnaires have been analyzed by using descriptive statistic technique. This section deals with the interpretation of data collected from students' questionnaire. Students' questionnaire was administered to know students perspective about the contents, skills, activities and general format of the textbook.

Table 1. Subject and content

\begin{tabular}{llllllll}
\hline Subject and Content & & & & & & \\
\hline & Statements & SA & $\mathrm{A}$ & $\mathrm{N}$ & $\mathrm{D}$ & $\mathrm{SD}$ & Mean \\
& & 5 & 4 & 3 & 2 & 1 & Score \\
\hline 1 & Relevant to students' needs & $20.5 \%$ & $13.5 \%$ & $11.5 \%$ & $11 \%$ & $43 \%$ & 2.57 \\
2 & Generally realistic & $34.5 \%$ & $27.0 \%$ & $5.5 \%$ & $21.5 \%$ & $11.5 \%$ & 3.52 \\
3 & Interesting and motivating & $27.5 \%$ & $26.5 \%$ & $6.0 \%$ & $22.5 \%$ & $17.5 \%$ & 3.24 \\
4 & Sufficient variety & $17.0 \%$ & $17.5 \%$ & $18.0 \%$ & $25.0 \%$ & $22.5 \%$ & 2.82 \\
5 & Not culturally biased & $21.0 \%$ & $17.0 \%$ & $13.5 \%$ & $22.0 \%$ & $25.5 \%$ & 2.83 \\
6 & Contents are logical & $22.5 \%$ & $21.5 \%$ & $5.0 \%$ & $12.5 \%$ & $13.5 \%$ & 2.52 \\
7 & Target language culture & $37.5 \%$ & $35.5 \%$ & $7.5 \%$ & $7.0 \%$ & $12.5 \%$ & 3.86 \\
8 & Contains real-life issues & $7.5 \%$ & $17.5 \%$ & $22.5 \%$ & $27.5 \%$ & $32.5 \%$ & 2.62 \\
9 & Variety of literary genres & $19.0 \%$ & $33.0 \%$ & $15.0 \%$ & $17.5 \%$ & $15.5 \%$ & 3.23 \\
\hline
\end{tabular}

\section{Subject and Content}

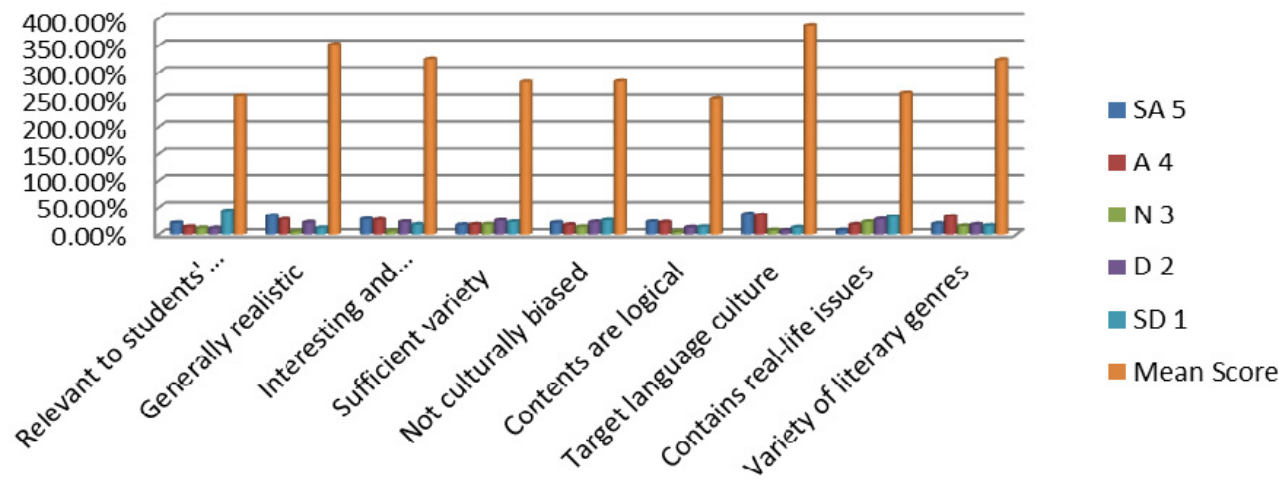

Figure 1. Subject and content of textbook

Table 1 and subsequent graph display the results collected about the subject and content of the text book. The data revealed that majority of the students claimed that the material is not relevant to students need and even not realistic. A large number of respondents opined that textbook lacks sufficient variety of language skills. However, some of them claimed that target culture was presented in the text as the mean score was 3.86; and real life issues have been discussed in the whole story as the measured mean score is 3.52 . However, the stories are not presented in logical sequence and this novel lacks variety of literary genres. 
Table 2. Vocabulary and grammar

\begin{tabular}{llllllll}
\hline Vocabulary and Grammar & & & & & & \\
\hline & Statements & SA & $\mathrm{A}$ & $\mathrm{N}$ & $\mathrm{D}$ & $\mathrm{SD}$ & Mean \\
& & 5 & 4 & 3 & 2 & 1 & Score \\
\hline 10 & Repetition of new words & $22.5 \%$ & $41.0 \%$ & $8.5 \%$ & $8.0 \%$ & $9.5 \%$ & 3.28 \\
11 & Presentation in a variety of ways & $9.5 \%$ & $18.0 \%$ & $22.5 \%$ & $13.5 \%$ & $11.5 \%$ & 2.26 \\
12 & Too many unknown words & $49.0 \%$ & $12.5 \%$ & $16.0 \%$ & $20.0 \%$ & $2.5 \%$ & 3.86 \\
13 & Adequate number of exercises & $8.5 \%$ & $11.5 \%$ & $9.5 \%$ & $22.5 \%$ & $48.0 \%$ & 2.10 \\
14 & Makes vocabulary learning easier & $29.0 \%$ & $31.0 \%$ & $5.0 \%$ & $25.0 \%$ & $10.0 \%$ & 3.44 \\
15 & Easy presentation of grammar & $22.5 \%$ & $41.5 \%$ & $10.0 \%$ & $12.0 \%$ & $14.0 \%$ & 3.47 \\
16 & Organization of grammar & $44.5 \%$ & $20.0 \%$ & $9.0 \%$ & $12.0 \%$ & $14.5 \%$ & 3.68 \\
17 & Progression of grammar & $23.0 \%$ & $9.0 \%$ & $15.5 \%$ & $17.5 \%$ & $65.0 \%$ & 2.98 \\
18 & Brief examples of grammar & $8.0 \%$ & $19.5 \%$ & $2.5 \%$ & $29.5 \%$ & $25.5 \%$ & 2.1 \\
\hline
\end{tabular}

\section{Vocabulary and Grammar}

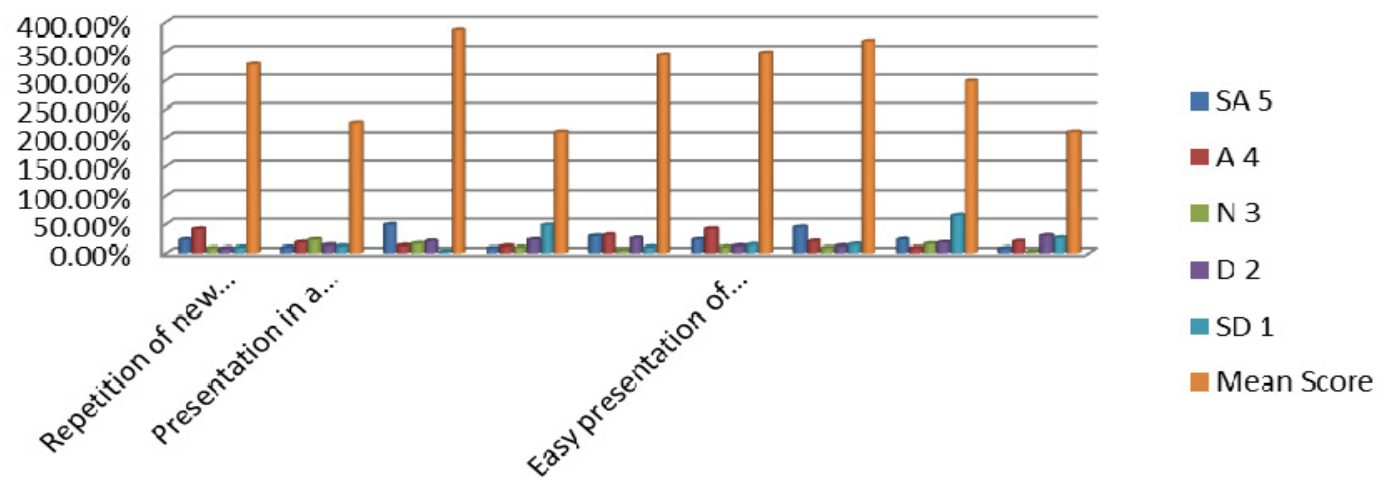

Figure 2. Vocabulary and grammar

Table 2 and following graph interpret the views of participants about vocabulary and grammar presented in the textbook. The respondents stated that there was little or no repetition of new words in this book. Moreover, the data also revealed that students were disagreed with the statement that the words were presented in variety of new ways. However they affirmed that they come across some most difficult words while reading text. Majority of the students told that exercises related to vocabulary learning are remote in the textbook. On the other hand grammar and grammatical rules were not presented in logical sequence. There were very few grammar exercises with few examples of grammatical rules in this book that create much difficulty in developing understanding of the readers.

Table 3. Exercise and activities

\begin{tabular}{llllllll}
\hline Exercises and Activities & & & & & & \\
\hline & Statements & $\mathrm{SA}$ & $\mathrm{A}$ & $\mathrm{N}$ & $\mathrm{D}$ & $\mathrm{SD}$ & Mean \\
& & 5 & 4 & 3 & 2 & 1 & Score \\
\hline 20 & Increase students' desire to learn & $26.5 \%$ & $24.5 \%$ & $9.0 \%$ & $16.5 \%$ & $23.5 \%$ & 3.14 \\
21 & Encourage collaborative work & $21.5 \%$ & $27.0 \%$ & $19.5 \%$ & $12.0 \%$ & $20.0 \%$ & 3.18 \\
22 & Interactive or task-based activities & $25.0 \%$ & $29.0 \%$ & $13.5 \%$ & $15.0 \%$ & $17.5 \%$ & 3.29 \\
23 & Facilitate use of grammar rules & $18.0 \%$ & $15.0 \%$ & $10.0 \%$ & $27.0 \%$ & $22.0 \%$ & 2.56 \\
\hline
\end{tabular}




\begin{tabular}{llllllll}
\hline 24 & Promote critical thinking & $16.5 \%$ & $13.0 \%$ & $12.0 \%$ & $18.0 \%$ & $40.5 \%$ & 2.65 \\
25 & Incorporate individual, group work & $31.5 \%$ & $28.0 \%$ & $11.0 \%$ & $10.5 \%$ & $19.0 \%$ & 3.36 \\
26 & Promote creative responses & $13.0 \%$ & $17.0 \%$ & $14.0 \%$ & $34.0 \%$ & $22.0 \%$ & 2.65 \\
27 & Modified or supplemented easily & $40.5 \%$ & $16.5 \%$ & $9.5 \%$ & $12.0 \%$ & $26.5 \%$ & 3.48 \\
28 & Conducive toward new language & $15.5 \%$ & $14.0 \%$ & $9.5 \%$ & $38.0 \%$ & $23.0 \%$ & 1.89 \\
29 & Help to improve reading skills & $18.5 \%$ & $46.5 \%$ & $3.5 \%$ & $13.5 \%$ & $18.0 \%$ & 3.35 \\
30 & Help to improve their writing skills & $28.0 \%$ & $36.0 \%$ & $9.0 \%$ & $11.5 \%$ & $15.5 \%$ & 3.49 \\
31 & Speaking activities & $11.0 \%$ & $8.0 \%$ & $12.5 \%$ & $32.0 \%$ & $36.5 \%$ & 2.25 \\
\hline
\end{tabular}

\section{Exercises and activities}

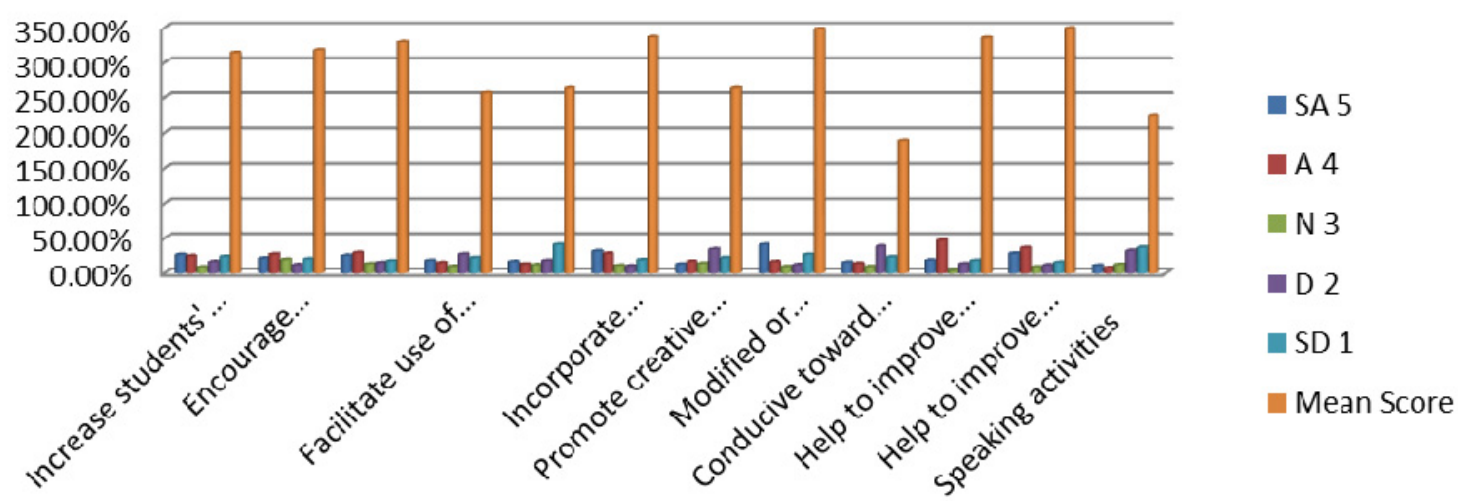

Figure 3. Exercise and activities

Table 3 followed by graphical representation presents the statistics about the exercise and activities given at the end of each chapter in this novel. The results revealed that majority of members disagreed with the statement that these activities increase the students' desire to learn and encourage them to collaborate with their fellows. Moreover, exercises also lack task-based activities and use of grammar rules. Participants also stated that these activities cannot be modified according to the students or learning needs. A large number of members were strongly disagreed that these exercises and activities are conducive towards learning new language. Additionally members stated that these activities do not help in improving reading skills nor writing skills or even speaking skills.

Table 4. Language skills

\begin{tabular}{llllllll}
\hline Language skills & & & & & & \\
\hline & Statements & SA & A & N & D & SD & Mean \\
& & 5 & 4 & 3 & 2 & 1 & Score \\
\hline 32 & Focus on the skills & $26.5 \%$ & $29.0 \%$ & $13.5 \%$ & $6.5 \%$ & $24.5 \%$ & 3.27 \\
33 & Balance of the four skills. & $11.0 \%$ & $9.0 \%$ & $18.5 \%$ & $7.0 \%$ & $54.5 \%$ & 2.2 \\
34 & Attention to sub-skills & $17.5 \%$ & $15.5 \%$ & $1.0 \%$ & $43.5 \%$ & $27.5 \%$ & 2.67 \\
35 & Practice of individual skills & $31.5 \%$ & $27.0 \%$ & $8.0 \%$ & $15.5 \%$ & $18.0 \%$ & 3.39 \\
36 & Inductive learning approach & $40.5 \%$ & $22.0 \%$ & $8.5 \%$ & $14.0 \%$ & $15.0 \%$ & 3.46 \\
37 & Facilitate teacher & $21.5 \%$ & $31.0 \%$ & $14.0 \%$ & $25.0 \%$ & $8.5 \%$ & 3.32 \\
\hline
\end{tabular}




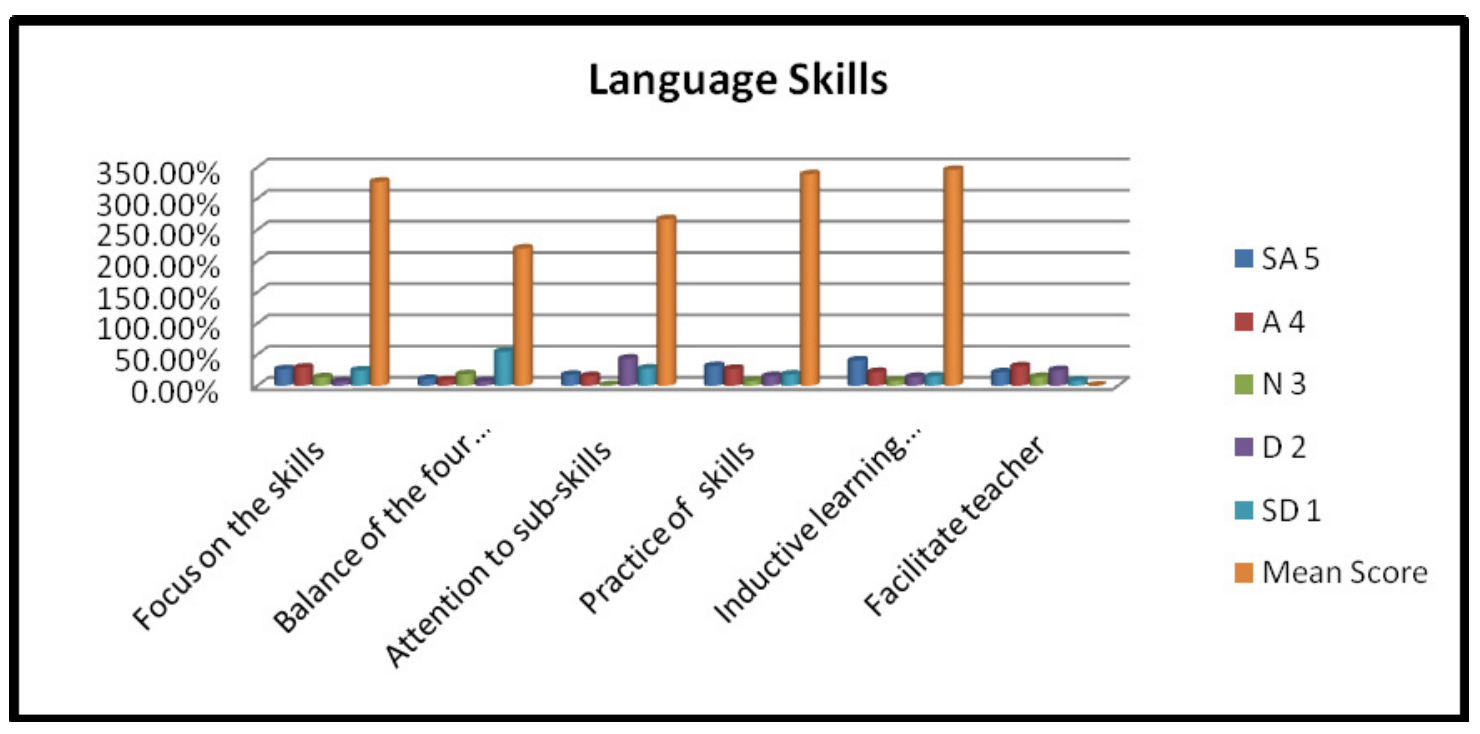

Figure 4. Language skills

Table 4 and subsequent graph displayed the results collected about the skills used in this novel. The data shows that majority of the respondents belonged to the category from disagree to neutral about the statements related to skills; like textbook focus on the all the four skills and sub skills as well. Moreover, they were slightly agreed that these exercises facilitate teachers toward inductive learning. Their overall mean values of individual statements show that students were not satisfied with the content and language skills used in the textbook. Findings also show that teachers do not have great command over teaching the insipid contents of the textbook.

\section{Discussions}

The students articulated dissatisfaction with the subject and content of the textbook and stated that there were no sufficient variety in subject and content of the textbook. Moreover, they claimed that subject and content of the textbook was not realistic and it lacks variety in offering challenges to them. Additionally, there is no logical and functional organization between subject and content of the textbook. They found the subject material culturally biased as well. Only some students claimed that textbook provides them the opportunity to think critically and change their worldviews. In contrast to this, some students were dissatisfied about the vocabulary and grammar items; the grammar exercises and adequate vocabulary were not included in the textbook. They further added that new vocabulary words were introduced in the text without any repetition which makes learning vocabulary difficult. Moreover, some students were not satisfied with the grammar exercises present in their textbook. Regarding the exercises and activities included in English textbook, majority of students claimed that exercises were not designed to encourage group work or even independent work. They cannot modify them according to their needs. Findings also show that textbook lacks task-based exercises and some students gave negative response on the contents and information. They did not find appropriate balance of the four language skills. Other sub-skills were also neglected in the books like listening for gist, note-taking, skimming for information etc. Additionally, students express their view that textbook did not encourage inductive approach towards learning language and it doesn't fulfill students' expectations.

The findings signify that majority of the students were not completely satisfied with learning objectives of textbook. However, related to some statements they show agreeable response that the objectives were measurable. On the whole, findings show that textbook did not fulfill the need of students at intermediate level. Moreover, the data also indicates that students were not completely satisfied with the textbook as these textbook did not raise their interest in doing further English language studies. Most of the students were dissatisfied about the appearance of textbook; they said that font size, format of the print and design of textbook was not appropriate. Moreover, it did not motivate them; neither appealed their interest towards learning language.

\subsection{Interpretation of Research Questions}

5.1.1 To what extent English textbook of grade 12 is effective in providing English Proficiency skills among ESL learners according to students' viewpoint? 
It is rather difficult, if not possible for any textbook to cater for the diverse needs of learners, the aims of syllabus, the constraints of situation and teaching styles, in any case, a textbook will be a compromise between learners need and what is available. No commercial book will ever be a perfectly fit for a language program (Richard, 2007). Taking these points in mind and the fact that the selection of textbooks is a major educational decision which has immediate implication for the quality of student learning, it can easily be appreciated. The findings of the study show that majority of students claimed that their textbook did not fulfill the criteria of providing an effective course for English language proficiency. On the subject of this question majority answered that the course book did not accomplish the criteria of good course book, the curriculum does not congregate interest in view of the fact that the examinations are just based on the theme of the texts which is outdated and of no authentic importance to the target learners. The textbook failed to inculcate English proficiency skills among learners.

5.1.2 How effective, English language teachers, relate the content and materials of textbook grade 12 towards their teaching practices and obtaining learning outcomes?

During investigation of textbooks and traditional language learning process, many textbooks are not up to date and may include language learning activities which are proved ineffective. Some textbooks provide guidance about activities which are not helpful for teachers and they fail to recognize the modern teaching methods according to students needs due to insufficient contents in textbooks. Many ELT textbooks are often regarded as the "tainted end-product of an author's or publisher desire for quick process. Findings reveal that most of the respondents thought that their most important aspire was to be capable to articulate in English confidently. In accumulation oral proficiency is the most favored language ability of the preponderance. On the other hand a comparatively higher proportion of the respondents assumed that the course book did not develop their speaking and listening skills. In the same way majority of learners did not stumble on the activities in the textbook. Concurrently extremely remarkable rate of the proportion supposed that neither the textbook enhanced their skills when taken as whole, nor increased their interest in language learning. Astonishingly (allowing for the majority's negative observations about the different aspects), overall respondents articulated dissatisfaction about the utility and effectiveness of textbook.

5.1.3 To what extent English textbook of grade 12 has been achieving curriculum goals and learning standards as devised by curriculum wing Pakistan?

Textbooks provide structure and curriculum for an educational program. They help standardize instruction and maintain equality; but the text book being used at intermediate level is unable to provide variety of learning resources. Moreover, it is unable to provide effective language models and input for visual learning materials. The findings also show that majority of teachers and students claimed that textbook being taught at grade 12 is unable to provide helpful indication for self-directed learning because it lack effective resources for presentation material. Effective source means a source of ideas and activities which can train teachers in order to achieve objectives as devised by curriculum wing. The objectives devised by curriculum wing, allow the teacher to set the learning process for students according to their experience. These objectives help to manage the lesson, discussion and provide process to learning and an authentic plan of action to teachers. However, the findings of the study displayed that the majority of the teachers believed that the chosen theme and material were not fulfilling the needs of ESL learners. To sum up, it is stated that majority of teachers claimed that textbook which is being taught at grade 12 does not fulfill learners need. They further added that this book did not provide them any help to develop an atmosphere where second language learning process becomes easy. They further added that textbook does not fulfill the demands of current age and provide no help in achieving goals as devised by curriculum wing of Pakistan.

5.1.4 What kinds of difficulties teachers and students come across while taking help from English textbook at intermediate level?

Textbook becomes source of guidance, motivation, inspiration and satisfaction for the students to fulfill their academic goals and objectives. Richards (2001) insists upon the vitality and usability of the textbooks by stating that textbooks are integral for any learning and teaching continuum. However, it is also important that textbooks must fulfill the purpose what they are designed for. Quite often, teachers and learners could not get as much benefit from textbook due to insipid material and vague activities provided in them. The findings of the study suggest that this book lacks consciousness or no notice towards students' concerns. That's why when students learn English language with the help of this textbook they face great difficulty. In addition the chosen text is not still ethnically suitable in view of the fact that they are out-of-date and the students can relay to only some part of it. Taken as a whole, the textbook is not catering to the learner's affective and educational requirements. More 
than that, teachers face great difficulty while preparing lectures for the students or execute their teaching from this textbook. They have to modify and change exercises according to the learners' needs. In addition, the materials do not contribute much in the development/improvement of fluency and accuracy, language ability, critical ability and creative writing.

\section{Conclusion}

The evaluation in present study highlighted a varied set of weaknesses which were found in the book Mr. Chips. The book is being taught in private and government. colleges for last many years. However, students feel discomfort and face many problems during their academic life at intermediate level. The book under discussion is void of attraction, interest and involvement. A large majority of the students affirm that book fails to provide relevant and effective linguistic skills among learners. Furthermore, findings also divulge that teachers don't use interest grabbing teaching activities while teaching textbook to learners. On the whole, it is inevitably needed to make appropriate and cogent modifications in the syllabus and materials being taught at intermediate level. Textbooks play significant role in teaching and learning process. Its importance is increased many times in case of language textbooks as teachers and students lack relevant and authentic material. Based upon the findings of this study and information gathered from other secondary data, it is strongly recommended to integrate innovative, interest grabbing and skill oriented materials in English textbooks. The contents of the textbooks must be in accordance with curriculum goals and learning objectives. Last but not least, it is also suggested to include instructional kits and teacher guides related to English textbooks. It will help teachers in their effective teaching and expedite the students' learning process.

\section{References}

Abbasian, R., \& Khajavi, Y. (2011). English Language Teaching, National Identity and Globalization in Iran: the Case of Public Schools. International Journal of Humanities and Social Science, 1(10).

Aftab, A., Sheikh, A., \& William, I. (2014). An Evaluation of English as a second language (ESL). Pakistani college textbook: Meeting the needs of Pakistani students.

Azizifar, A., Koosha, M., \& Lotfi, A. (2010). An Analytical Evaluation of Iranian High School ELT Textbooks from 1990 to the present. Social and Behavioral Sciences, 3, 36-44.

Foster, S. (2002). Methodological Issues and Approaches in Textbook Research and Analysis. Unpublished instructional document, Institute of Education, University of London.

Fredriksson, P., \& Olsson, R. (2006). English Textbook Evaluation: An Investigation into Criteria for Selecting English Textbooks. Cambridge University Press.

Government of Pakistan. (2006). National curriculum of English language for grades 1-12. Islamabad.

Hrehovcik, T. (2002). Foreign language textbook evaluation-methodological considerations. Retrieved from http://www.univ.rzeszow.pl/fil_ang/usar1/sar_v1_18.pdf

Hussain, M. M., \& Mahmood, K. (2002). Aazad Jammu and Kashmir Textbook Evaluation. Unpublished Study Commissioned by World Bank. Islamabad: Semiotic International. https://doi.org/10.21236/ADA404200

Lathif, M. (2015). An Evaluation of English textbook for the Eighth Grades of Junior High School. Faculty of languages and arts Yogyakarta State University.

McDonough, J., \& Shaw, C. (2003). Materials and methods in ELT: A teacher's guide (2nd ed.). Oxford: Blackwell Publishing.

McGrath, I. (2002). Material Evaluation and Design for Language Teaching. Edinburgh: Edinburgh University Press.

Nguyen, C. T. (2015). An evaluation of the textbook English: 6 A case study from secondary schools in the Mekong Delta Provinces of Vietnam.

Richards, J. C. (2001). Curriculum development in language teaching. Cambridge Language Education, Cambridge. https://doi.org/10.1017/CBO9780511667220

Skierso, A. (1991). Textbook selection and evaluation. In M. Celce-Murcia. Teaching English as a second or foreign language (2nd ed., pp. 432-453). Boston: Heinle \& Heinle Publishers.

Zohrabi, M., Sabouri, H., \& Behroozian, R. (2012). An Evaluation of Merits and Demerits of Iranian First Year High School English Textbook. English Language Teaching, 5(8), 14-21. https://doi.org/10.5539/elt.v5n 8 p14 


\section{Copyrights}

Copyright for this article is retained by the author(s), with first publication rights granted to the journal.

This is an open-access article distributed under the terms and conditions of the Creative Commons Attribution license (http://creativecommons.org/licenses/by/4.0/). 